\title{
The British Influence in the Birth of Spanish Sport
}

\author{
Antonio Rivero Herraiz and Raúl Sánchez García*
}

Universidad Europea de Madrid

Sports started to gain relevance in Spain around the end of the nineteenth century and the beginning of the twentieth century as a leisure and health option of the upper classes imported from Britain. Its early development was intertwined with the spread of other kinds of physical activities with much more tradition on the continent: gymnastics and physical education. First played by the ruling classes aristocracy and high bourgeoisie - sports permeated towards petty bourgeoisie and middle classes in urban areas such as Madrid, Barcelona, San Sebastián and Santander. This pattern meant that the expansion of sports was unavoidably tied to the degree of industrialisation and cultural modernisation of the country. Since 1910 , and mainly during the 1920 s, sport grew in popularity as a spectacle and, to a much lesser degree, as a practice among the Spanish population.

Keywords: sport; Spain; gymnastics; modernisation

\section{L'influence britannique sur la naissance du sport espagnol}

Le sport a commencé à devenir significatif en Espagne autour de la fin du dixneuvième siècle et au début du vingtième siècle à la fois comme loisir et comme l'un des moyens importés de Grande-Bretagne pour développer la santé des classes supérieures. Ses premiers développements s'entrecroisent avec la diffusion d'autres formes d'activités physiques beaucoup plus traditionnelles sur le continent: gymnastique et éducation physique. D’abord pratiqué par les classes dirigeantes - l'aristocratie et la haute bourgeoisie - le sport a pénétré la petite bourgeoisie et les classes moyennes des zones urbaines comme Madrid, Barcelone, Saint-Sébastien ou Santander. Ce modèle signifie que l'expansion du sport a été inévitablement liée au degré d'industrialisation et de modernisation culturelle du pays. Depuis 1910 et surtout pendant les années 1920, le sport a accru sa popularité comme spectacle et, à un moindre degré, comme pratique au sein de la population espagnole.

\section{La influencia británica en el nacimiento del deporte en España}

El deporte empezó a adquirir importancia en España hacia finales del siglo XIX y principios del siglo XX como una actividad de ocio y de salud para las clases altas importada del Reino Unido. Su desarrollo inicial estuvo imbricado con la difusión de otros tipos de actividades físicas con mucha más tradición en el continente: la gimnasia y la educación física. Inicialmente practicado por las clases dominantes - la aristocracia y la alta burguesía-, el deporte se difundió más adelante entre la pequeña burguesía y las clases medias en áreas urbanas como 
Madrid, Barcelona, San Sebastián o Santander. Este esquema comportó que la expansión del deporte se viera inevitablemente vinculada al grado de industrialización y de modernización cultural del país. Desde 1910, y especialmente durante los años 20, el deporte fue adquiriendo popularidad como espectáculo y, en un grado mucho menor, como práctica entre la población española.

\section{Der britische Einfluss auf die Entstehung des spanischen Sports}

Gegen Ende des 19. und zu Beginn des 20. Jahrhunderts erlangte der Sport in Spanien, als eine aus Britannien importierte Freizeitbeschäftigung und Möglichkeit zur Gesundheitsförderung der oberen Klassen, Bedeutung. Seine früheste Entwicklung war eng verbunden mit der Ausbreitung weiterer Bewegungskulturen, die auf dem Kontinent viel größere Tradition hatten: die Schwedische Gymnastik und das Deutsche Turnen. Diese wurden zu Beginn von der Elite - Aristokratie und Großbürgertum - ausgeübt und verbreiteten sich schließlich auch unter den Kleinbürgern und der Mittelklasse in Städten wie Madrid, Barcelona, San Sebastián oder Santander. Dieses Entstehungsmuster verdeutlicht, dass die Verbreitung des Sports zwangsläufig mit dem Grad der Industrialisierung und der kulturellen Modernisierung des Landes verknüpft war. Seit 1910, vor allem aber in den 1920ern, avancierte der Sport in der Bevölkerung zum Spektakel und regte, allerdings in viel geringerem Umfang, die spanische Bevölkerung zur aktiven Ausübung an.

\section{英国对西班牙体育起源的影响}

体育运动在西班牙得到普遍的认同是从19世纪末和 20 世纪初, 体育被上层阶级当做一种休闲 健康的生活选择从英国引入开始的。它的早期发展是与欧洲大陆各种传统的身体锻炼形式不断 向外传播交织在一起的，如体操和身体教育。那些起初被统治阶层一贯族和上层资产阶级所喜 爱的运动，也不断向下层小资产阶级和中产阶级渗透，这些现象发生在一些大城市，如马德里、 巴塞罗那、圣塞瓦斯蒂和安桑坦德。此外，作者认为，这种现象意味着体育的扩张不可避免地 与工业化和文化的现代化程度相关。1910年以来，主要是在20世纪20年代，体育普及程度不 断加深已成为一种普遍的社会现象，在西班牙也得到了较小的程度的体现。

\section{Introduction}

At the end of the nineteenth century, members of the aristocracy and bourgeoisie from Madrid and Barcelona, influenced by British culture, started to play English sport $^{1}$ as a distinctive activity and a sign of social status. ${ }^{2}$ Sport 'travelled' with these social classes to their leisure places, where it would continue to be played by the local inhabitants, as happened in San Sebastián and Santander, from where sport spread to the rest of the north of Spain. The direct influence of the British Empire through its merchant navy and the British colony settled in Spain was felt definitively in the expansion of sport around the country.

Later, the petty bourgeoisie and urban middle classes (professional class, civil servants, traders, administrative assistants, bank clerks and so on), from big cities started to do exercise, mainly physical and sporting activities. It was a kind of emulation of the upper classes and of the modern and distinguished habits associated with English society. A healthy objective and social prestige were the values most attached to sport at this time. 
Before presenting in greater detail how sport evolved throughout Spanish society we must first get a better understanding of the kind of sports exported from Britain. These sporting activities were developed within and attached to the growing influence of the middle classes, a progressive and reformist group that changed the way society was organised as a whole; sport was an important means through which such a goal was attempted.

\section{The Middle Classes' Sports Revolution: From British Public Schools to Continental Europe}

When we talk about modern sport undoubtedly we should refer to its specific development in Britain initially. Although we can find a clear precedent in the pastimes of British aristocrats during the seventeenth and eighteenth centuries ${ }^{3}$ sport as it is understood nowadays was established within the public-school system and also in the clubs and societies of imperial Britain during the nineteenth century. This process was achieved thanks to the arduous reformist efforts of the middle classes of the Victorian and Edwardian eras. ${ }^{4}$ Between 1870 and 1920 this cultural phenomenon spread quickly across the colonies and also continental Europe, helped by Pierre de Coubertin's Olympic movement. Spain was no exception.

But what type of sport was germinating during that time? What were the values and practices attached to it? To answer these questions we must present briefly the way sports were introduced and moulded within the public schools' curriculum during the nineteenth century.

Public schools were educational institutions preparatory to university entry for upper-class and upper-middle-class people. These institutions constituted in themselves a microcosm, a kind of laboratory where the future leaders of British society and the British Empire would be formed. In this laboratory the rules of sports and primitive ways of playing were going to germinate.

Before 1850 sports were not part of the formal curriculum of the public schools. The leisure activities of the boys were outside the control of the directive board and consisted in the so-called field sports, such as hunting, shooting and fishing, all of them related to the landed aristocratic ethos of the eighteenth and nineteenth centuries. However, from the middle of the nineteenth century, sporting games started to be introduced, spreading through the institutions as an educational aim in themselves, ending in a general movement known as athleticism. ${ }^{5}$ Such educational reform, based upon the introduction of sports as a means of building a strong character, has been linked to the figure of Thomas Arnold, headmaster of Rugby School. None the less, other headmasters were also connected to this movement, even though historically they have not been recognised as much as Arnold. The true importance of Arnold dwells in his role as a middle-class representative against the aristocracy in the struggle for the control of upper-class education (of those who later would lead society in different fields). Public schools started to breed a new form of masculinity, attached to the figure of the sporting gentleman ('an aristocrat of character, not of birth'). ${ }^{6}$ Through these games, they were supposed to develop autonomy, initiative, self-sacrifice, effort, courage and emotional self-control values that conformed to what later became known as fair play.

These former public-school pupils brought with them these new sport practices to the university and later to society. They occupied important positions in different influential professions and they built a network of clubs and associations for the 
practice of sport. The cult of athleticism spread, linked to the middle classes, the true representative of amateurism, a condensation of bourgeois values such as respectability and honourable competition.

Sports such as golf, lawn tennis or yachting were used by the professional middle classes to celebrate a common set of values and practices. Moreover, some of them (e.g. doctors) appeared in many cases as leaders of local sport organisations. The lower stratum of the middle class (e.g. clerks or teachers) took part in cycling or gymnastics societies. Between both groups, those pertaining to the middle range (merchants, marketers and shopkeepers) practised sports such as athletics.

But sport was spreading not just throughout British society. In the period between 1870 and 1920 there was a huge movement of sport expansion towards continental Europe. The agent facilitating this transfer and arrival of sport to mainland Europe was the vast commercial network associated with the British Empire. These middle classes led a world revolution through their sportisation. ${ }^{8}$ This process was favoured by the strong fellow-feeling of the bourgeois middle classes across Europe during that time. Physical exercise was linked to health morally, physically and socially. This new revolutionary bourgeoisie tried to establish a new society, composed of a new ideal citizen; one of the main tools at hand for this purpose was the use of sports. This "sporting humanism" ${ }^{, 9}$ tried to instil the character and moral virtue of the gentleman into the population.

The same phenomenon happened in Spain: the so-called middle-class Regeneracionistas ('Regenerationists') saw sport as the booster of a revitalising and modernising energy in a demoralised nation embroiled in defeatism. None the less, the expansion of sports in Spain presented its own peculiarities. This expansion process occurred as Spanish society began to understand sport as a fresh, cosmopolitan activity held in high esteem by the social, military and political powers.

\section{Regenerationism, Sport and the Modernisation of the Nation}

During the years between the last decade of nineteenth century and the Second World War, European public opinion - and that of many Governments - started to equate sporting success with the value of 'race', the praising of the homeland and the power of the nation. International competitions organised by federations and the Olympic Games, driven by the IOC, established themselves as a suitable frame in which to show in a peaceful but efficient way national potential and the international prestige of nations and countries. Good sports results were swiftly extrapolated to national success in other spheres. In the Spanish case sport also had other implications, linked to the demands of regeneration and reform that permeated the country's public life from the beginning of the twentieth century: any good international performance was, for our sport 'regenerationists' a hopeful starting point for the recovery of the 'debilitated race'. The failure of our willing but poorly trained athletes revealed the lack of a national sport organisation and the low level of interest in physical culture in our society.

Several circumstances made PE and sport become a means for modernising fin de siècle Spanish society. When Joaquín Costa published Reconstitución y Europeización de España ('Reconstitution and Europeanisation of Spain') in 1899 and two years later Oligarquía y Caciquismo ('Oligarchy and Despotism'), the core principles for national regeneration were established. Little by little these ideas started to gain authority in Spanish public opinion and society as a whole. 
Regenerationist thinking was defended by representatives of the new middle classes living in urban areas. They wanted to bring about a reorganisation of the Spanish society. They backed the idea of agrarian reform (developing irrigation), a better and more encompassing education, efficient economic and administrative reforms, the end of despotism as the main political structure; in other words, they aimed for a general modernisation of the country. As Costa stated, this process could only be achieved through a progressive Europeanisation of Spanish social and political structures. Europe was, for the regenerationist, the beacon that would guide the ship of Spanish awakening; the solution for the so-called problem that Spain constituted. The regenerationist discourse about social, political and administrative reforms permeated slowly but surely. These ideas were paramount to back up claims about the need to introduce sport and physical culture into Spanish society. Physical regeneration and the modernisation of hygienic and cultural habits through sports were the main goals for the Spanish sport pioneers.

The problem of a weakened race in other countries was mainly linked to the dreadful working conditions of the working classes - the root of serious health problems. In Spain the situation was slightly different: although it had a considerably lower number of working-class members (due to a less developed industrial sector), the main problem was first and foremost the consideration of Spain as a nation in itself and of the Spanish people as a 'race'. Moreover, just when European countries were showing their superiority to the world (fulfilling their colonising and civilising mission towards those who were considered lower primitive peoples), Spain lost in 1898 the parts of its old empire in a humiliating manner.

However, some benefits were gained from this situation. Repatriated capital coming from Cuba and Puerto Rico favoured new investments in the country. In addition to his, Spanish neutrality during the First World War helped the recovery of industrial production and modernity that lagged behind the rest of Europe during the nineteenth century. It was just during this epoch - the first third of the twentieth century - when Spanish society organised definitively the basis of sporting practice, coinciding in time with the fastest economic development and the greatest modernising spurt known so far by the country. ${ }^{10}$ Clear changes occurred between 1910 and 1936. Spanish society was approaching the social conditions and lifestyles of other well-developed nations. If we look for ways of telling traditional societies from modern ones - for example, industrialisation, urbanisation and labour specialisation $^{11}$ - we witness that from the beginnings of the twentieth century (more clearly from the second decade) the Spanish advance towards modernity was remarkable.

With the Great War, the proportion of the population emigrating to foreign countries suffered a clear decline and internal migrant movements increased: more than 1,100,000 people changed residence during the 1920s. Madrid, Barcelona, Valencia, Seville and Bilbao were the main reception areas of the rural exodus, which went to the cities to work in the industrial and services sector. From $66 \%$ of the employed population working in the countryside in 1910 , the figure fell to $45.5 \%$ in 1930. From 1900 illiteracy decreased from $55 \%$ to $27 \%$ at the end of the $1920 \mathrm{~s} .{ }^{12}$ In a vast number of cities, especially the largest, the growth and development projected in the nineteenth century was completed: squares, streets, official buildings, sports stadiums, stations, bullrings, cinemas and, above all, housing. In this fashion, cities were consolidated as centres of modernisation, generators of new cultural and social relations - sometimes causing confrontation - among people who tried to find their 
right place in order not to lose prominence in the new urban structure. Sport started to be constituted as a new cultural urban element. Sport was understood as a cultural must for any society that wanted to be considered modern. That was the feeling of the English, Americans, French and Italians; that was the feeling of Spanish pedagogues, the military, doctors, university students, journalists, artists and other influential social groups as well. That was precisely why the middle classes started to play sports, conceiving them as a distinctive trait that would get them closer to modernity. The excellent athlete and journalist Federico Reparaz wrote in 1919 a work titled Ante la Olimpiada - Datos para la Historia ('Facing the Olympics - Data for History'), published in the Eco de Sports and depicted in Heraldo Deportivo, where he talked about the recommended participation of Spain in the Antwerp Olympics and the role of sport in society in general.

Additionally, this should provide us with an awareness about the long journey that remained before sport would be mentioned in every conversation, finding a place in news columns, spreading its true meaning among people of all ages and social class, and abandoning its position as the exclusive leisure practice of a few to carry out the very important role that every nation aspiring to be modern or alive has assigned to it. $^{13}$

Not only economic and social aspects were changing but there were cultural changes as well. The German historian of literature and ideas Ernst Robert Curtius expressed in his Critical Essays on European Literature in 1949 that 'The awakening of the Spanish culture is one of the few pleasant events of the twentieth century'. ${ }^{14}$ That is, when sport emerged as an alternative to the traditional customs of the working classes (tavern-related activities such as smoking, drinking and playing cards, bullfighting, flamenco and so on). The sport-promoting regenerationists presented this new activity as a way to social change and modernisation. ${ }^{15}$

\section{Gymnastics, PE and Sports in Spain}

Before British sport started to gain recognition in Spain and continental Europe in general, gymnastics and physical education already had some trajectory there. During the nineteenth century these three elements blended together, constituting the physical culture of the country. The chronology of the origins and establishment of this varied group of physical activities in Spain requires some distinctions to be made: firstly, about the origins themselves; and secondly, about the content of such physical practices.

Referring to the origins of gymnastics and physical education, the key date was 1806, when Colonel Francisco Amorós created the Real Instituto Militar Pestalozziano (The Royal Pestalozzian Military Institute) in Madrid with the approval of Carlos IV. This institute was a pioneering one in Europe related to the introduction of gymnastics and physical exercise as the basis of education. During the War of Independence, Amorós collaborated with the French Joseph Bonaparte, and at the end of the war, with Napoleonic troops having been defeated, he had to leave, exiled to France. His gymnastic systems succeeded in Paris, being adopted later by the French Army during the whole of the nineteenth century. His work disappeared in Spain due to the lack of successors; Francisco de Aguilera $y$ Becerril, Count of Villalobos (1817-1867) or José María Aparici y Biedma (1824 1894) were the only remarkable exceptions to such complete abandonment of Amorós's legacy. 
Another key year was 1883, when the first Physical Education Law was passed, during Sagasta's government. The progressive member of parliament Manuel Becerra was the one to defend it most eargerly. José Luis Albaraleda, Ministry of Promotion, responsible for the public instruction and a member of the Liberal Party, expounded solid arguments - coinciding with those of Becerra - to declare gymnastics official, making clear the English influence as a support of his ideas:

I'll do my best from such bench and within the attributions I have, not only to contribute through gyms in the primary and secondary schools, but to influence and inflate the passion about the development of the physical organism in this country. The ridiculed word of English sport, and I use this as there is no other term to substitute for it, is a hymn to the country's life and exercise and it constitutes - that is my feeling about it - not just a trend or a trivial pursuit but a civilising means of advance and the development of the individuals composing our society. ${ }^{16}$

The most significant thing was that, even during these first attempts to introduce gymnastics or sport in the official educational system, such physical culture had a regenerative, civilising, modern and progressive vein. Sport appeared as a regenerative and patriotic activity and Spain wished to follow the example of countries where physical exercise was already established in the schools.

Intellectuals and influential circles of society viewed sport within $\mathrm{PE}$ as a very positive thing. Personalities such as Giner de los Ríos, Manuel B. Cossío and the founders of the Institución Libre de Enseñanza (known as 'institutionalists') boosted sports among scholars, ${ }^{17}$ and decided to apply English pedagogical methods, considered as a model to follow due to their prestige and efficacy. ${ }^{18}$ By contrast, they rejected and distanced themselves consciously from French-based patriotic gymnastics. In fact, the gentleman archetype was always present for the institutionalists:

The English educational style is backed up in some articles as in 'On the current defects of the Institución Libre de Enseñanza' written by Francisco Giner de los Ríos: 'The sentiment of personality (sincerity, courage, self-help, honour, etc.), the care and development of physical strength and manners are the three determining qualities - in my opinion - of English education'. ${ }^{19}$

None the less, sport was not accepted as the perfect educative tool by all; it attracted a few critics from a section of the Spanish intelligentsia. Santiago Ramón y Cajal (one of the main Spanish scientific eminences of the epoch), wrote about sports in his memoir called El mundo visto a los ochenta años ("The World as Seen by an Octogenarian'). ${ }^{20}$ Cajal was in favour of Spanish popular games and criticised by way of contrast the snobbish attitude of accepting the foreign as better than the native. He considered spectator sport as an 'exaggeration', as was seen by many other Spanish intellectuals of these days. Sport professionalism was the worst of the enemies.

Spanish society, prone to ask for state protection, aspired to gain the protection of the administration in the sphere of PE and sport formation for youth in the school centres. The administration reacted as it could; essentially passing laws that most times were not really executed, due to lack of political will or due to the lack of human and economic resources. That was the picture during the Restoration, the Primo de Rivera dictatorship or the Second Republic: no government was able to regulate efficiently $\mathrm{PE}$ in schools, despite important claims with good criteria and 
educational views advising of the importance of $\mathrm{PE}$ for the health and good development of upcoming generations.

The implementation of PE laws would have been of great importance in setting up healthy habits among the Spanish population. But it is doubtful that simply with official backing such physical and hygienic customs would have flourished there. Before 1936, there was a lack of not only sporting organisation and structures, but an adequate social and cultural environment as well. The development of sport practice would have required, in order to be effective, a parallel and complex social dynamism and cultural modernisation that simply did not exist. Later, the growth of the social and political crisis in the Second Republic and the outbreak of the Civil War in 1936 ended any hope in this direction.

The situation of PE would take a century to become a reality, to be a well planned and taught subject with full pedagogical consequences within the school system. The Central School of Gymnastics, created in 1887 as a result of the law passed in 1883, would close in 1892 due to the lack of means for maintaining the institution and the lack of interest shown by the educational authorities.

During the First World War and the aftermath, in every European country there was a growing interest from the military in athletic sports (mainly football) as a training tool. This was true not only in nations participating directly in the war but also in the neutral countries. The reason was that the military considered these activities appropriate for the physical conditioning of troops. Something similar occurred in Spain. In December 1919, General Villalba laid down the rules that would govern the PE school of Toledo's Infantry Academy. Sports appeared alongside traditional gymnastics within the syllabus. ${ }^{21}$

The decisive years for the beginnings of Spanish sport were the end of the 1880s. The decisive places were those where British commercial and economic influence brought the 'importation' of these cultural and sporting habits. The influence of the British mining colony - composed of technicians and workers from Spanish-British companies working on copper and iron - was a major factor. That was especially important in the region of Andalucia, where the initiative of such collectives led to the creation of clubs and the consolidation of sports habits, continued later by the native population. The British Rio Tinto Company Limited operated the copper mines of Huelva from 1873, when they were bought from the First Spanish Republic for 92 million pesetas (solving a very difficult financial situation for the government). Workers and technicians of the company organised and founded a club for their cultural, sporting and leisure enjoyment: all the players were foreigners. That is why until 1889 this doyen of the Spanish football clubs was not officially recognised. It was called Club Recreativo de Huelva and it showed the clear influence of the British mining community. The same influence can be observed in the Lawn Tennis Club Riotinto, founded in 1891. In 1914, Club Balompié Río Tinto was founded, composed mainly of local players, and the mining company built an official football field. By 1920, there were more than 20 football teams in the region, evidence of the vast influence the British colony had had there on the spread of sporting activities. Apart from Andalucia, other parts of Spain received the influence of British working colonies as well: the Canary Islands, especially Las Palmas de Gran Canaria, which received English shipping companies operating in the ports. Activities such as football, cricket, golf and tennis played by the workers were first watched and then copied by the local population. In that sense, the figure of Sydney Montague Head (1876-1945) was especially relevant. Arriving at the Canary Islands at the end of the 
nineteenth century, he played a prominent role both as player and as manager of cricket, golf and tennis, becoming Spanish champion during 1907 and 1909 in the last discipline. ${ }^{22}$

As a result of the good reception for British activities, Las Palmas Golf Club was founded in 1891, Las Palmas Lawn Tennis Club in 1894 and the Gymnastics Club (with a football team and also organising cycling races) in 1907. The first international sports event hosted in Las Palmas was the cricket match between Madeira's Excelsior Cricket Club and Las Palmas Cricket Club in 1901.

Private gyms were in some cases the seedbed of Spanish sport as well. These gyms were created around the middle of the nineteenth century. Dr Vignolles set up a gym in Madrid (1851) where important personalities such as Manuel Becerra (member of parliament and minister) or José Canalejas (member of parliament and president between 1910 and 1912) were members. In 1860, Joaquín Ramis opened the first gym in Barcelona. In 1882, there were seven gyms in Madrid, five of them with fencing halls and two (those of Mariano Ordax and José Sánchez) almost exclusively with a therapeutic orientation. In Barcelona, during the years of the Universal Exposition, there were already five gyms, growing in numbers in the $1890 \mathrm{~s}^{23}$ If we check the journals of this era, gyms played a double role: on the one hand, they were places to practise an aristocratic sport, where fencing halls were the main core, fencing being the Spanish sport par excellence. On the other hand, they acted as promoters of British and other athletic sports such as football, athletics, cycling and so on.

These gyms, mainly around the Catalonian area, can be considered as the associative embryo of Spanish sport. They offered the chance to develop different activities such as excursions and cycling trips, to do some British sports or even skating and dancing. ${ }^{24}$ So big was the British influence in these moments that even disciplines coming from other parts of the globe - such as Japanese ju-jitsu - were considered from the sporting perspective, being practised by sportsmen, a movement developed mainly around Barcelona, where the associative structure made possible a better reception for such kinds of activities. ${ }^{25}$ The first sportsmen were considered as extravagant people or snobs and only little by little did their practice start to be recognised as containing a positive and beneficial influence. Madrid, Catalonia and later the Basque Country and other urban centres were the first cores of the incipient Spanish sporting phenomenon.

Whereas aristocratic sports such as horse riding, hunting and yachting continued to be practised by socially exclusive minorities, competitive sports of English origin were slowly developed thanks to private initiative. Soon, a different kind of practice and interest in them among different social strata started to be observed. On the one hand spectator sports such as football and boxing were followed in big numbers by the popular classes. On the other hand, sports such as athletics, rowing (see Figure 1), swimming, hockey and cycling were practised as healthy activities, forgers of certain moral values, the basis of Olympism.

\section{The Germ of Spanish Sports Associations: the Spanish Gymnastic Society}

It would not be until the end of the 1890s and the beginnings of twentieth century that some action was taken in the creation of societies and clubs. These organisations helped to articulate definitively the organisation of some sports. Apart from the first (but restricted) gymnastic clubs (Circulo Particular Gimnástico, Madrid, 1851), the Outing Associations (Associació Catalanista d'Excursions Cientifiques, 1876) and the 


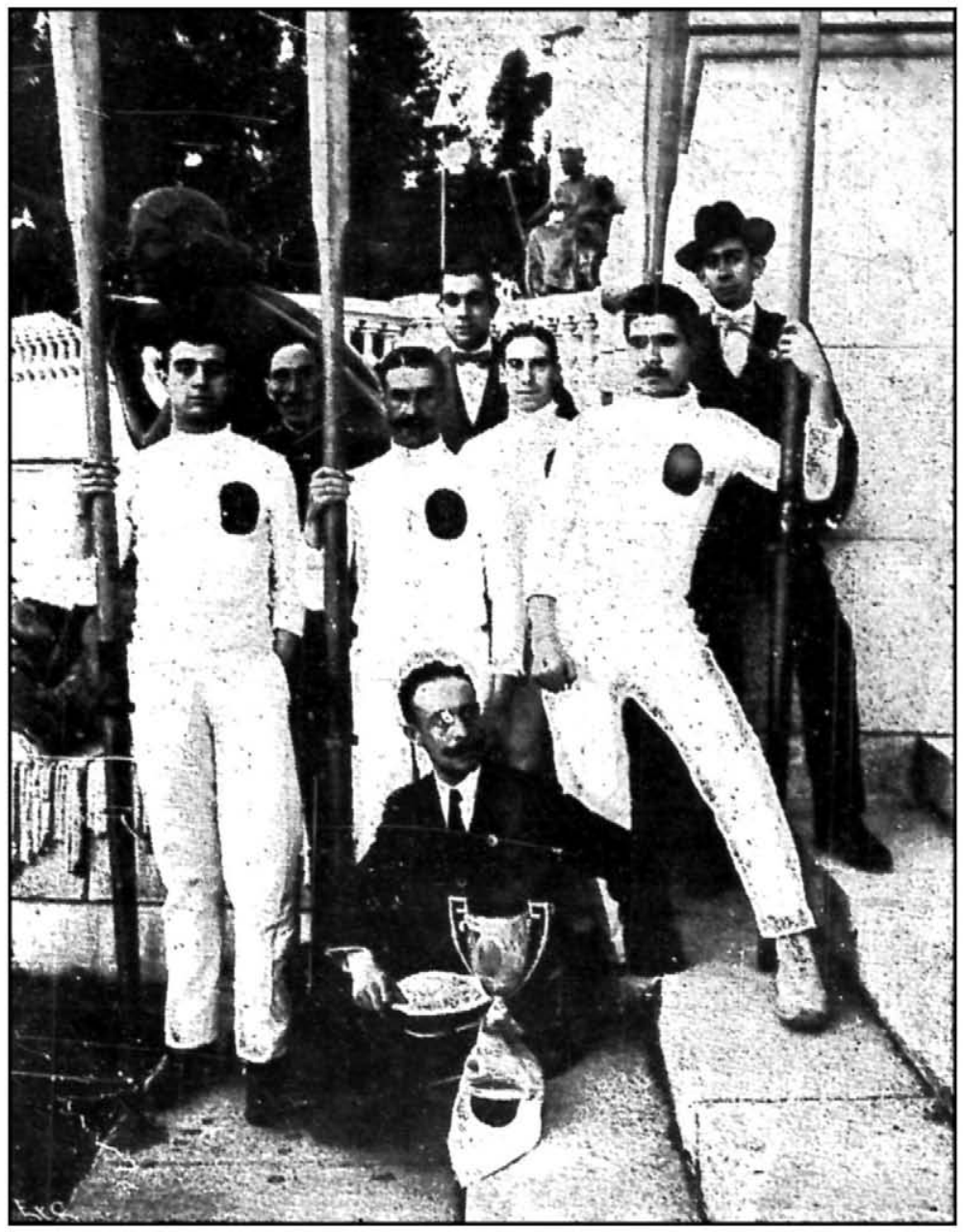

Figure 1. Rowers in the Retiro pond. Source: Gran Vida, no 160, 1916: 313.

clubs with an aristocratic vein (centred on horse riding, lawn tennis and yachting), we can point to the Spanish Gymnastic Society, founded in Madrid in 1887, as the pioneer association of the Spanish sport. At least, that was the treatment given by the specialised press in 1912, during the 25th Anniversary of the 'Gimnástica', as it was commonly known:

Throughout the course of 25 years struggling and sacrificing energy, initiatives and constant work - dedicated to the development of PE, interest in sports, and the fight against vices that spoil youth - the goodness and wisdom of the idea has been demonstrated....

Four young men with courage, initiative and, above all, with a true faith in sport, agreed in a friendly conversation, on 2 March 1887, to work with all their energy in order to set in motion a popular and democratic society that would set sports within reach of any fan; the student, the employee, the worker could fight against the vices and stultification of a slave's life, of constant work, thanks to the expansion and balance that the emotions in sports offer to the spirit, achieving a harmonic development of intelligence and health. ${ }^{26}$ 
We can check again how the objective of modernisation, democratisation and the regeneration of Spanish society through PE and sport was clearly present among the press and the driving forces of physical activity. The Spanish Gymnastics Society (see Figure 2) enjoyed widespread respect and admiration:

All of the daily, illustrated and sports press have paid attention, with great detail and without sparing praise, to the celebration of the festivities. El Mundo Deportivo, from Barcelona, ended by saying: the Gimnástica can be very proud of the show it put on, carried out in the most brilliant way. Let all the Spanish sportsmen's hearts unite to continue working as they have been doing so far in order to celebrate - if possible - with a bigger success, the golden jubilee. ${ }^{27}$

Its work was rewarded by King Alfonso XIII, who bestowed the title of 'Royal' to the society in $1916 .^{28}$

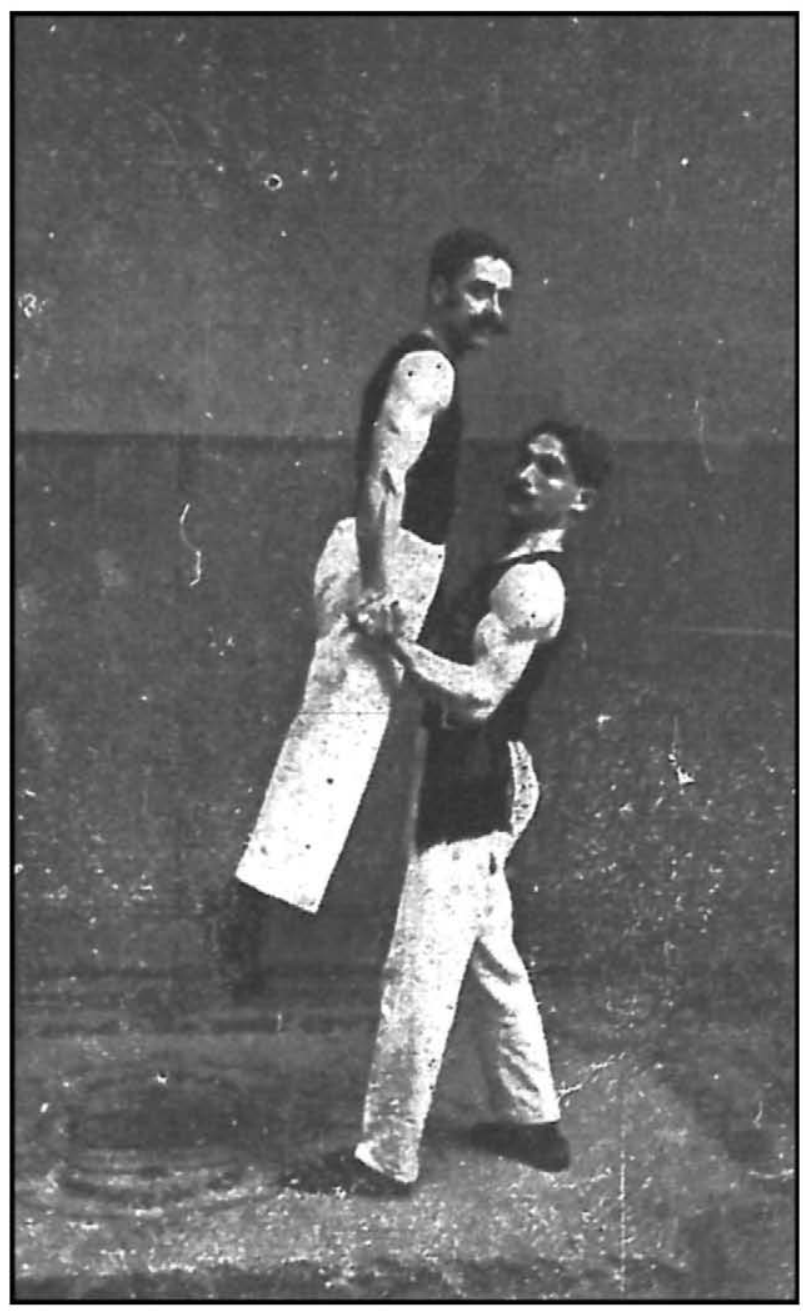

Figure 2. Members of the Royal Spanish Gymnastic Society exercising. Source: Gran Vida, no 106, 1912: 80. 


\section{The Structuring of Spanish Sport Organisation}

Although the initiatives of the 'Gimnástica' were enthusiastic, not every sport society worked with the same strength and success. To consolidate the organisation of a sport system took a long time. The first sport clubs were formed in Madrid and their practices were carried to San Sebastian by the aristocracy and the bourgeoisie during holidays. Sport clubs were born in Madrid, San Sebastian and Santander. Bilbao was also a pioneering centre of sporting clubs (the Football Club Athletic de Bilbao was founded in 1898) due to the direct British influence through its merchant navy's activity: the same ships bringing charcoal to Spain were going back with iron ore to be used in iron manufacture. Even so, Catalonia, and especially Barcelona, were the first places where the most solid and extended club system was set up. As Lagardera states,

Particularly in its existence and dynamism, the overwhelming appearance of sport societies in Barcelona between 1888 and 1900 is remarkable, doubling the number of sport clubs all around the country, when in the north, centre and south of Spain the first sport societies had been created some years earlier. ${ }^{29}$

The rest of Spanish sport appeared scattered all around the national territory, always within urban settlements, related to social groups in the sphere of the liberal professions (lawyers, judges, journalism and so on), industry and market traders. Such groups understood physical activities as a dynamic and healthy way of social modernisation. For instance, the Tarragona Gymnastic Club had from its beginning in 1895 a clear vocation for sports promotion, its football section being one of the oldest of the Spanish clubs. Three years later, on 1 May 1898, Narciso Masferrer y Sala, from the journal Los Deportes, issued a call to every Spanish sportsman to set up the Spanish Gymnastics Societies Confederation. Favourable to the proposal were the Gymnastic Club of Tarragona, the National Official Teachers Association (a corporate society founded by gymnastics teachers after the closure of the official school), Vigo's Gym, the Gymnastics Club of Cartagena, the Gymnastics Society of Orense and the Catalan Gymnastics Society (set up one year before by Catalan gymnastics clubs). After overcoming some reticence - probably related to the majority presence of Catalan members among the driving forces and future managers of the association - the Spanish Gymnastic Society confirmed its adhesion as well, and in June the first executive committee of the new confederation was constituted in Madrid. José Canalejas - who was the honorary president of the Catalan Gymnastic Association - was appointed as the president. ${ }^{30}$ On 15 June 1898 , an article signed by Masferrer about the formation of the new body was published in Los Deportes magazine. We must remember that during those moments the gymnastic societies were the promoters of gymnastic practice and sports. It would take some time for the latter to develop in an independent way, forming their own associations and federations. We quote the article in length due to its importance in order to know the pioneers of the Spanish sport system:

And to applaud and celebrate my idea, Mr Sanz, representative from Tarragone; Mojardin, from Barcelona; Ordax, from Orense; López Ferreira from Girona; Parera from Madrid; and Coll, as a foundational member of the doyen of our societies, talked in succession, giving eloquent speeches, full of energy and good doctrine, summing up the eloquent and thoughtful discourses of Dr Sanmartin [sic], everyone agreeing to join in the struggle to achieve an approach to PE as found in the most developed nations. The problem is difficult but with good will and our enthusiasm to guide us, there is no doubt that quite soon we will see the justifiable wishes of the gymnastic societies and their 
members fulfilled. Every speaker had words of praise for our SPORTS, to such kindness and friendliness I responded with gratitude.... And before ending I have to make public my expression of thanks for the attention the Madrid delegates had offered to those from the provinces and the tokens of affection and sympathy I have been given. ${ }^{31}$

The registered office of the confederation was set in the offices of the Spanish Gymnastic Society and the Barcelonan magazine Los Deportes would be its official diffusion instrument. The minutes of the constitution meeting deserve a closer look. Firstly, the mention of 'our sports' corresponds to the already mentioned importance of the gymnastic societies in sports promotion in general. This statement is consistent with the presence of Marcelo S. Sanz and José Robles, supporters of the spread of the new sports within the heart of the Spanish Gymnastic Society. Secondly, we confirm the importance in number of Catalan managers and entities - who must be credited with the initiative of the confederation - and the omnipresence of the Spanish Gymnastic Society, with its founders, as the oldest association. Lastly, it has to be stressed that this was the first time the Spanish term deporte (sport) was substituted for the traditional English term sport as the name of a journal or a magazine. On 15 July there appeared in Los Deportes the list of provincial representatives of the Spanish Gymnastic Society and on 26 September the first general assembly report was published. ${ }^{32}$

\section{The Consolidation of the Spanish Sport System}

From 1910 we can talk about a slow but increasing implantation of sport all over Spain. The advance of sports and physical activities was parallel to the process of social modernisation that occurred between 1910 and 1936. This fact is confirmed by the same chronology in the foundation of sporting clubs and federations of regional and national scope. Although many of the first initiatives came from Madrid, Barcelona was the Spanish city with the greatest sporting awareness. Catalonia was the Spanish region that first achieved the design and consolidation of a more or less organised sport structure. Afterwards, following the Catalonian capital's initiative mainly from 1910 onwards - new clubs were set up in Madrid, Guipúzcoa and Vizcaya, constituting the nation's large-scale sporting structure. These were the same areas that acted as the motor of the Spanish productive, economic and cultural life until the Spanish Civil War (1936-9). Those were places where, despite the many existing social problems, the concern for education, culture and technical progress was evident. As we witnessed, a suitable social atmosphere for economic and cultural development and industrial technological advance also favoured the development of physical activities and sports. ${ }^{33}$ In Spain, as in Europe, sports appeared as a phenomenon inevitably bound to the urban culture of the first third of the twentieth century.

The consolidation of the sport system was not easy as the constitution of the sport federations was continually subject to questioning and misunderstandings. Sometimes, the Spanish sport system was polarised between Madrid and Barcelona. However and despite these facts, some modes of understanding prevailed on most occasions: neither Madrid's centralism nor Catalan radicalism was strong enough to overcome the spirit of cooperation among the sports managers in both cities. As for the other great core of Spanish sport, the Basque Country, its relation with Madrilenian sport was always very close and there were never any of the tensions that existed between Madrid and Barcelona. ${ }^{34}$ In order to understand this situation, 
it is enough to revisit some of the specialised press of these days, where sport news from Madrid, Bilbao or San Sebastian were given the same importance and the criteria and sport values of different journals presented great homogeneity.

\section{Technology and Modernity: Motor Sports}

Motor sports were considered as full sports from the very beginning. ${ }^{35}$ Long aeroplane trips (raids) and car competitions (rallys) were very popular with sports fans from the first days. The interest aroused by these new machines, the spirit of adventure and the influence of the English concept of a 'record' (récord in Spanish) were, without doubt, the key points for these sports to be successful. Even so, these kinds of activities were restricted to the very few. Perhaps at a time when sport was being popularised and spread to the lower classes, the most elevated classes found in the new motor sports what had been represented by hunting and horse riding: a distinctive sign of class and social position.

Technology and sport were going hand in hand in geographic-sporting exploits of great relevance. In Spain, aviation was the sports spectacle that would gain the admiration of citizens and fans before any other; the heroic achievement of the flying boat Plus Ultra, arriving in Buenos Aires after crossing the Atlantic Ocean in February 1926, was - according to the press - one of the biggest exploits of the Spanish nation in recent times. The journal Heraldo Deportivo reported the joint manifesto of the organisers, read in the streets of Madrid, acclaimed by a boundless national enthusiasm (see Figure 3):

To the Spanish nation:

Niña, Pinta, Santa Maria, Plus Ultra. Evoking the sacred names of the 1492 caravelles that have represented our trajectory during four centuries, and placing next to these humble crafts of Columbus the sublime aircraft, scientific culmination of the twentieth century, linked by the nexus of heroism, there would not be any Spanish heart unmoved, nor any Spanish mother feeling less than the ones of those days; because the race survives, we can say it very loud. And if the sun sets on our horizons its light did not die in the hearts of the sons of the presentd-day mothers. Franco, Ruiz de Alda, Durán and Rada have been a good example. Spaniards: these new heroes of our history are the torch bearers of the heroic deeds from the past; they went over the immense ocean as shelter and with Plus Ultra as a motto. The frenetic acclaim of the South American Nations received them: they are sisters of language, religion and race; yesterday our aviators reached the shores of their continent and tomorrow they'll reach the margins of the River del Plata; they risked their lives for Spain and have fought to put its name on the peak. ${ }^{36}$

The journey was valued in three different but equally important aspects: political, scientific and sporting, the last being indisputable. These were the records achieved by the Spanish flying boat during the trip: Spanish distance record (Las PalmasCabo Verde), 1,665 km; Portuguese distance record (Porto Praia-F. Noronha), $2,235 \mathrm{~km}$; speed record for $1,500 \mathrm{~km}$ (over $180 \mathrm{~km}$ per hour); speed record for $2,000 \mathrm{~km}$ (over $180 \mathrm{~km}$ per hour). In total, the trip was $10,000 \mathrm{~km}, 70$ hours in flight and 19 days in duration. This success was widely reported by the international press, especially USA and England, and encouraged further long-distance flying by Spanish aviators.

Referring to motorbike competitions during those years, the situation evolved from the very first contests organised in Madrid's Retiro park and the uphill races in Rabbassada or Montserrat in Barcelona to the circuit races of Lasarte and Sitges 


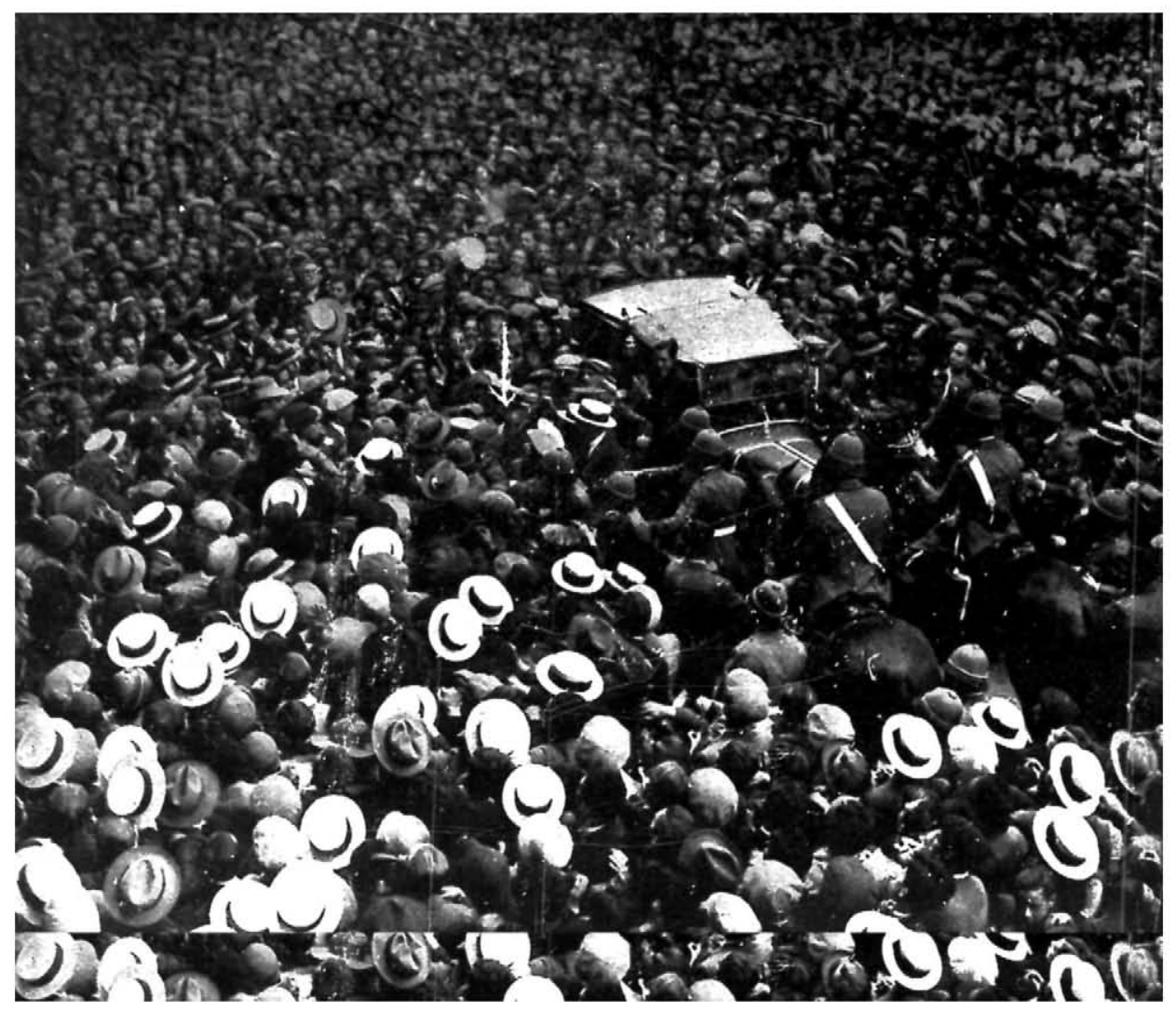

Figure 3. A big welcome to the heroes of Plus Ultra.

Source: Heraldo Deportivo, no 321, 1924: 183.

and later to the spectacular 'dirt-track' speedway imported from the UK, where it was already a professional sport. Massive crowds attended this spectacular discipline. Little by little, Barcelonan and Madrilenian riders caught up with the British motorbikers who were considered until then the competing aces in Spanish stadiums. The sporting press of the 1930 s presented speedway as one of the most exciting and interesting spectator sports for the public.

\section{Other Kinds of Activity: Professional Sports}

Public opinion has accepted little by little - especially since the 1920 s - sports as a means of entertainment and spectacle. Sports such as football and boxing (and cycling slightly later) were followed in big numbers by the general population. In a few years, football and boxing would steer towards professionalism. In 1926 professional football (see Figure 4) was legalised and a big national competition could be foreseen, using as a reference the English league model. After some difficulties, on 23 May 1928, the project of a national championship league with ten teams was inaugurated.

Boxers, frequently coming from low strata, especially the urban proletariat, went in search of earnings from the 'purse' of their bouts. During the 1930s it was, 


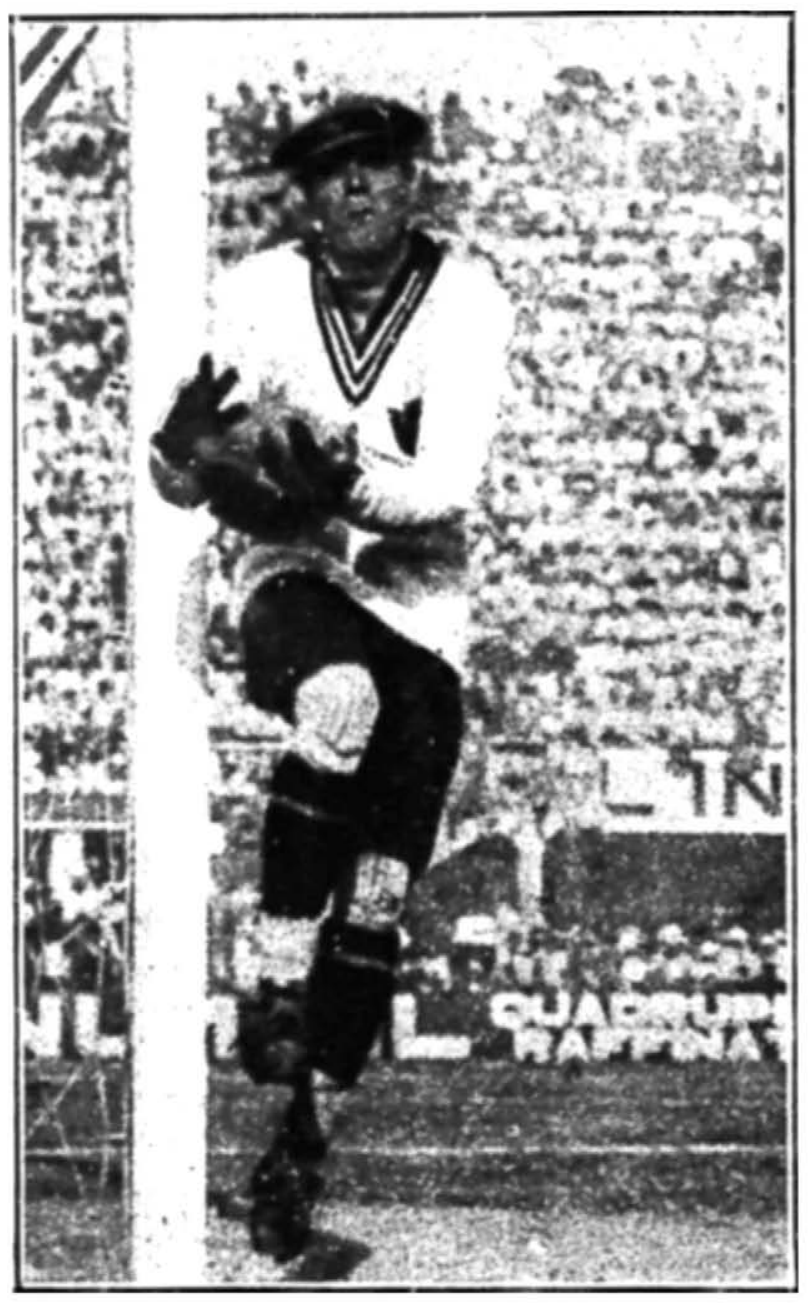

Figure 4. Ricardo Zamora, Amberes Olympics (1920) medallist and first Spanish professional football player.

Source: Gran Vida, no 343, 1932: 20.

with football, the most popular sport. Great champions as Uzcudun, Ara, Gironés or Sangchilli (the last becoming world champion in 1935), made boxing a spectacle that brought in big crowds of fans in sporting halls, pelota courts and football pitches, all of them adapted for the occasion of the boxing bout.

Cycling (organised in 1896 around the Spanish Cycling Union), after a period of stagnation, experienced a resurrection as a spectator sport in the 1930s with the participation of Spanish cyclists (Vicente Trueba, Ezquerra, Cañardo, Montero) in the Tour de France. In 1935 the First Spanish Cycling Tour (Vuelta Ciclista a España) took place, sponsored by the journal Informaciones and the Cycling Tour of the Basque Country returned to the circuit, acting in conjunction with the Catalonian Cycling Tour - celebrated since 1910 - as a booster for cycling to become a spectator sport. 


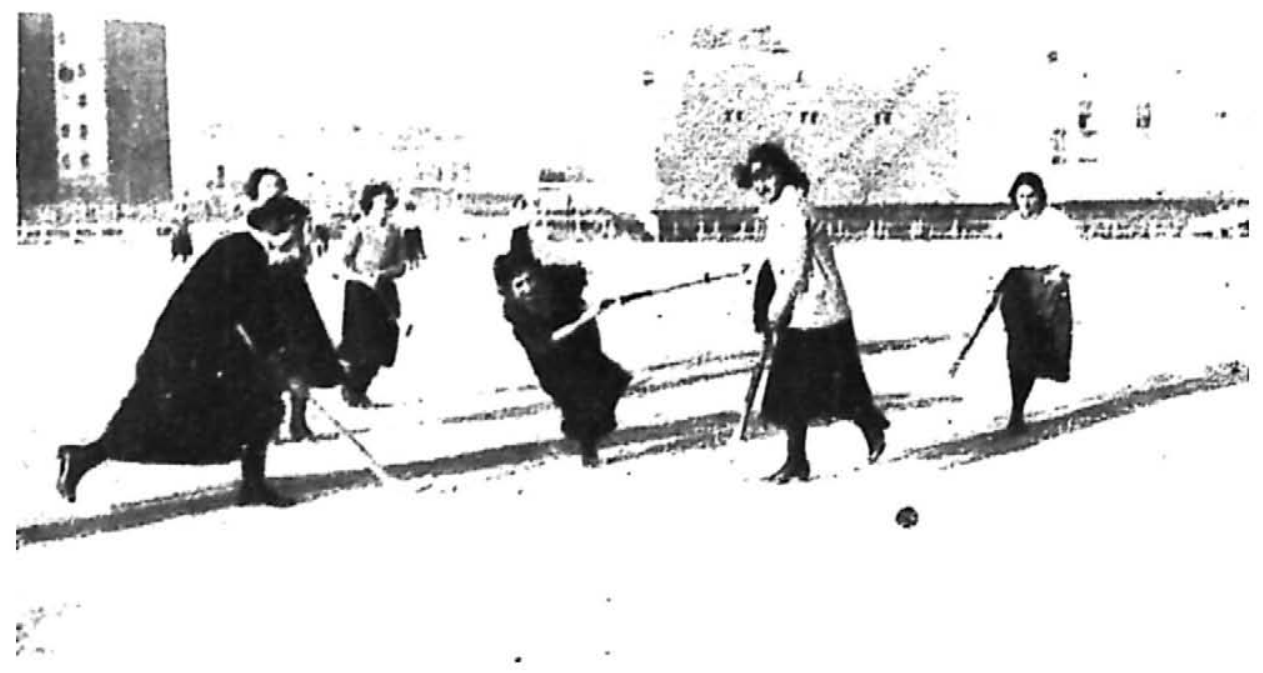

Figure 5. Atlético de Madrid ladies playing hockey.

Source: Heraldo Deportivo, no 208, 1921: 58.

In an article in the Heraldo Deportivo we can witness the increasing preoccupation about professionalism and its spread to other sports:

The progress of football as a spectacle, a sure index of its decadence as a sport, constitutes a true danger, too late to avoid.... The football trick of spectacle masks a ruined stagnation of the sport, whose core of participants is not doing well, neither in quality nor in quantity. ${ }^{37}$

Professional sport was not seen by some intellectuals as a 'good example' for the general population. The identification of football with the general development of sports and its assimilation into PE and physical culture shocked the purists, supporters of physical activity as a means of education and social regeneration. From these sectors football was guilty of promoting professionalism and economic interest, distorting in this way the real sporting goal.

\section{Sport and Women}

Female sport started within selected social circles of the upper classes, spreading from the large urban settlements. It was deeply attached to the regenerationist idea of hygiene and health, with its main goal being for the values of maternity and care to prevail. The ideal example of physical activity for women was found in the English and Scandinavian female:

Referring to the perfection of race, the English female sportsman ${ }^{38}$ firstly bears healthy offspring and then makes them strong through sports.... In Sweden, ladies' schools have a gym where the Ling method is practised. Out of school they do not quit gymnastics, registering in several societies with teachers leading physical exercises in special premises or in halls of the Central Institute in Stockholm. 
In 1923, Spanish women already practised hockey, tennis, gymnastics and so on in Madrid, Barcelona, Bilbao, San Sebastian and other cities (see Figure 5). There were clubs in some of these places and the sport press called for the organisation of a national competition - as was the case of men - especially taking into account the fact that cities such as Seville, Vigo and Jeréz had started to show some activity in female sports. In the sports magazine Gran Vida we can find some opinions about female hockey during these days:

In our past issue we already explained the reasons and emotion contained in Hockey. Of course, in this respect we agreed on the superiority of football; but the former wins over the latter in sportsmanship, at least nowadays. Very few hockeyistas [hockey players] hold the reputation of dirty players; this is because, above all, the players practising hockey normally show pure sportsmanship.

And here is the reason why we consider hockey most appropriate for the beau sexe. ${ }^{40}$

In 1931, jointly with the first Spanish Decathlon Championship, the first Spanish Female Athletics Championship took place in Madrid, organised by the Madrilenian Athletic Society. This national female athletics contest indicated the coming of a new sporting awareness. The 1930s would bring an opening-up of Spanish society to the world, coinciding with the establishment of the progressive political environment of the Second Republic (1931-6), whose educational, cultural and social policy favoured female incorporation into new spheres of the social order, sport being one of these. The outbreak of the Spanish Civil War in 1936 halted this process.

\section{Spain within the Olympic Movement}

The Olympic Movement in Spain was supported mainly by the same regions and cities that constituted the flesh and bones of the Spanish sport system. Pierre de Coubertin acknowledged Barcelona as a sporting city after his visit in $1926 .{ }^{41}$ Of course, Barcelonan sports development was not comparable with other regions, much less with rural areas. But it can be thought that if the 1936 Olympics had been held in Barcelona, probably the historic valuation of Spanish sport previous to this date would had been more positive.

How did Europe see Spain within the Olympic movement? The vision expressed by the organisation committee of the Berlin Olympics is telling:

Spain's reputation as a sporting country is not as well known in the world as it deserves. The truth is that until now, it has not shone with success in the Olympic Games. Whereas during the Amsterdam Olympics, in 1928, it took part in nine different disciplines, in 1932, during the Los Angeles Olympics, it participated only in pistol shooting and sailing, finishing fourth in both activities.

For this reason, and the world press has commented upon it, the brilliance of the Spanish team competition in the Football Championship, recently held in Rome is so remarkable. Effectively, if there is a country where football is truly popular this is Spain.

The fame of the magnificent goalkeeper Ricardo Zamora has spread all over the globe. Madrid and Barcelona are the two centres of Spanish sporting life. In Barcelona's beautiful stadium a really informed public has congregated many times to witness the great international championships and the sports press in both cities enjoys great activity.

If in the cities the main sports are football, hockey, boxing, swimming and tennis, in the rest of the country it is mixed with people's lives, the same as dancing, pelota games, 
jai alai, the latter figuring already in the Olympics election programme. The simple fact that the election of the 11th Olympics was held in Barcelona is in itself of special interest. There, in the beautiful Mediterranean city, the IOC in 1931 decided that the Olympic Games of 1936 would take place in Germany's capital. ${ }^{42}$

Football, already completely professional, appeared as the highest exponent of Spanish sport. This was a clear demonstration of the difference in prestige and popularity between professional and amateur sport in the country.

The mention of Basque 'pelota' in the text is very significant. This game, apart from being a very popular activity in the capitals and rural areas of the north of Spain (the Basque Country, Navarra and some areas of Castilla León), emerged elsewhere. In Madrid, for instance, the Basque Sport Club was founded in 1904 with the aim of promoting pelota. Even though it never represented a real alternative to British sports, pelota always conserved its position among traditional customs; and, as a great achievement to be mentioned, was an exhibition sport in both the Paris and Berlin Olympics.

\section{Concluding Remarks}

Spain displayed a certain delay in the sporting field compared to other countries, but this was not absolute, e.g. Spain was one of the founding nations of the international football associations. British sporting influence was noticed, especially in those areas where the contact with locals was stronger (e.g. the ports of the north and the Canary Islands, and the mining companies of Andalucia) and big cities (Madrid, Barcelona, Santander, San Sebastián, Bilbao) where aristocrats and the rising urban middle classes were in touch with cultural habits imported from modern nations. Of those two social groups the latter would have the most prominent role in spreading a particular way and values attached to sport. Their conditions of living were attached to specific areas, characterised by particular social and cultural features: big cities and very crowded regions with certain solidity in their economic structure, zones already embarked on the industrialisation process and where the productive system was already set up.

In a nutshell, sport in Spain was a means of cultural expression and manifestation of the urban middle classes who wanted to give their lives the taste of modernity that was prevailing in other more powerful countries. Of course, their aims were neither economic nor commercial at the beginning; sport until 1936 was not offering any guarantee about material benefits. Sport appeared associated with health and vitality, with a new positive attitude towards life. The development of sport in Spain, as in other European countries, was a sign of social, economic and cultural modernisation.

\section{Notes on Contributors}

Antonio Rivero Herráiz has a BA in sport sciences (UPM-INEF) and a $\mathrm{PhD}$ in geography and history (UCM). He has published several papers and books on the historical development of Spanish sport. Currently he is a lecturer in the social sciences department at UPM-INEF.

Raúl Sánchez García, (UEM-CAFYD) has a BA and PhD in sport sciences (UPM-INEF), and an MA in the sociology of sport (Leicester). He has published several papers on the sociohistorical development of Spanish sport. Currently he is a lecturer in the social sciences department at UEM-CAFYD. 


\section{Notes}

1. Along the text we will make a distinction between sport -'deporte' in Spanish- and sport (in italics) -the English term used in the Spanish literature since 1873, being 'El sport español' ('The Spanish sport') the first sport newspaper, published in Barcelona in 1885. Later, sport ('deporte') started to be used circa 1894 by writers as Emilia Pardo Bazán and in some sport press -'La Ilustración Artística' and 'El deporte velocipedo' in Madrid or 'Los Deportes' in Barcelona- that will expand the new use (Rivero Herraiz, Deporte $y$ Modernización, 24). After a period of cohabitation of both terms, sport ('deporte') finally prevailed. The use of the Spanish term deporte instead of sport is unusual among other European and World countries and its lexical origins can be traced back to the twelfth century, as it has been extensively researched (see Piernavieja, 1966, 'Depuerto, deporte, protohistoria de una palabra'; Trapero, 1979, El campo semántico "Deporte"; Fernández, 1971, 'Sport y deporte. Compuestos y derivados'). According to Trapero: 'our current sport has a double nature: from the content side it is a semantic Anglicism but from the lexicum side it is an old Castillian expression or a provenzalism' (El campo semántico "Deporte", 288).

2. Lagardera, Actas Congreso Cientifico Olimpico 1992.

3. Elias and Dunning, Quest for Excitement.

4. Mangan, A Sport Loving Society.

5. Mangan, Athleticism in the Victorian and Edwardian Public Schools.

6. Park, 'Biological thought, athletics and the formation of a man of character: 1830-1900', 7.

7. Lowerson, Sport and the English middle classes 1870-1914.

8. Mangan, A Sport Loving Society, 2.

9. Mangan, 'Middle class revolutionaries in pursuit of moral, Physical and social health'.

10. Payne, Franco, el perfil de la Historia.

11. Alvárez Junco, '¿Modernidad o atraso? Sociedad y cultura política', 71.

12. Julía, Un siglo de España, Política y sociedad, 45-49.

13. Reparaz, F. 'Ante la Olimpiada - Datos para la historia', Heraldo Deportivo no 166, 1919: 473. (Underlined is ours).

14. Fusi, J.P, Un siglo de España. La cultura, 13.

15. Rivero Herráiz, Deporte y Modernización.

16. Quoted in Piernavieja, La educación Física en España, antecedentes histórico legales.

17. Among different sports, outing was always present to people coming from the Institución Libre de Enseñanza. Some of the outing societies would become very well known sporting clubs as the Spanish Alpine Club, Peñalara etc...In Catalonia, the main initiatives were attached to the Catalanist Scientific Outing Association of Barcelona.

18. López Serra, Historia de la E. Física. La institución libre de enseñanza.

19. Ibid, 186.

20. Ramón y Cajal, El mundo visto a los ochenta años.

21. Vinuesa Lope and Vinuesa Jiménez, La Escuela de Gimnasia de Toledo.

22. Almeida Aguiar, Británicos, deporte y burguesía en una ciudad atlántica.

23. Lagardera, Actas Congreso Cientifico Olímpico 1992, 15.

24. Ibid.

25. Gutiérrez García, Introducción y desarrollo del Judo en España.

26. 'El XXV aniversario de la Sociedad Gimnástica Española', Gran Vida no 106, 1912: 73 74. Madrid (Underlined is ours).

27. 'El XXV aniversario de la Sociedad Gimnástica Española', Gran Vida, 106, 1912: 81-82.

28. The 'Gimnástica' suffered a schism in 1889 that gave birth to the creation of the National Gymnastics Association. Nonetheless, the latter rejoined the Spanish Gymnastics Society in 1891 (Lagadera, Actas Congreso Científico Olímpico 1992, 17).

29. Ibid, 16 .

30. Ibid, 19.

31. Masferrer, Los Deportes, 15 June, 1898: 288.

32. Sanz, Primera asamblea general de la Federación Gimnástica Española. Madrid.

33. Rivero Herráiz, Deporte y Modernización.

34. Ibid.

35. Press used to refer to the first car drivers as 'distinguished sportmen'.

36. 'Página Gloriosa', Heraldo Deportivo no 387, 1926: 59. 
37. Heraldo Deportivo, no 240, 1922: 15.

38. The term sportwoman was not used by the Spanish sport press yet.

39. López Serra, Historia de la E. Física. La institución libre de enseñanza, 186.

40. El «hockey» y el feminismo', Gran vida, no 235, 1923: 13.

41. Durántez, La academia Olímpica Internacional.

42. 'Olimpismo', Heraldo Deportivo, no 690, 1934: 183-184.

\section{References}

Almeida Aguiar, A.S. Británicos, deporte y burguesia en una ciudad atlántica (Las Palmas de Gran Canaria 1880-1914). Palmas de Gran Canaria: Universidad de Palmas de Gran Canaria, 2005.

Álvarez Junco, J. ‘¿Modernidad o atraso? Sociedad y cultura política'. In Debates en torno al 98, ed. S. Julía, 71. Madrid: Consejería de Educación y Cultura de la Comunidad de Madrid, 1998.

Durántez, C. La academia Olímpica Internacional. Navarra: C.O.E., 1989.

Elias, N. and E. Dunning. Quest for Excitement. Sport and Leisure in the Civilizing Process. London: Blackwell, 1986.

Fernández, A. 'Sport y deporte. Compuestos y derivados'. Citius, Altius, Fortius XIII (1971): 291-307.

Fusi, J.P. Un siglo de España. La cultura. Madrid: Macial Pons, 1999.

Gutiérrez García, C. Introducción y desarrollo del Judo en España (de principios de s.XX a 1965). León: Universidad de León, 2004.

Hernández Coronado, M. 'Comentarios al XI Campeonato de España de Decatlon y I Femenino de Atletismo'. Gran Vida 340 (1931): 339.

Julía, S. Un siglo de España, Política y sociedad. Madrid: Marcial Pons, 1999.

Lagardera, F. Actas Congreso Cientifico Olimpico 1992. Málaga: Instituto Andaluz del Deporte, 1995.

López Serra, F. Historia de la E. Física. La institución libre de enseñanza. Madrid: Gymnos, 1998.

Lowerson, J. Sport and the English Middle Classes 1870-1914. Manchester: Manchester University Press, 1995.

Mangan, J.A. Athleticism in the Victorian and Edwardian Public School. London: Frank Cass, 2000.

Mangan, J.A. 'Middle Class Revolutionaries in Pursuit of Moral, Physical and Social Health'. In Reformers, Sport, Modernizers: Middle Class Revolutionaries, ed. J.A. Mangan. London: Frank Cass, 2002.

Mangan, J.A. A Sport Loving Society: Victorian and Edwardian Middle-class England at Play. London: Frank Cass, 2006.

Mangan, J.A. and C. McKenzie. 'The Other Side of the Coin: Victorian Masculinity, Field Sports and English Elite Education'. European Sports History Review. Vol. 2: Making European Masculinities. London: Frank Cass, 2000.

Park, Roberta J. 'Biological Thought, Athletics and the Formation of a Man of Character: 1830-1900'. In Manliness and Morality, eds J.A. Mangan and J. Walwin, 7-34. Manchester: Manchester University Press, 1987.

Payne, G. Franco, el perfil de la Historia. Madrid: Espasa Calpe, 1993.

Piernavieja, M. La educación Física en España, antecedentes histórico legales. Madrid: C. Bermejo, 1962.

Piernavieja, M. 'Depuerto, deporte, protohistoria de una palabra'. Citius, Altius, Fortius VIII (1966): 5-190.

Ramón y Cajal, S. El mundo visto a los ochenta años. Madrid: Tipografía artística, 1934.

Rivero Herraiz, A. Deporte y Modernización (La actividad Física como elemento de transformación social y cultural en España, 1910-1936). Madrid: Consejería de Cultura y Deportes de la Comunidad de Madrid, 2003.

Sanz, M. Primera asamblea general de la Federación Gimnástica Española. Madrid: Imprenta Central de los Ferrocarriles, 1899.

Trapero, M. El campo semántico 'Deporte'. Santa Cruz de Tenerife: Caja General de Ahorros, 1979.

Vinuesa Lope, M. and Vinuesa Jiménez, I. La Escuela de Gimnasia de Toledo. Toledo: Exc. Diputación Provincial de Toledo, 1995. 


\section{Appendix 1. Foundation Dates of Spanish Sport Federations and Spanish Olympic Organisation}

1894 Pigeon fancying

1894 Cycling

1896 Gymnastics

1899 Olympic target shooting

1909 Lawn-tennis

1909 Football

1912 Spanish Olympic Committee

1918 Athletics

1920 Swimming

1922 Mountaineering

1924 Basketball, boxing, hockey, rugby, motorcycling

1924 Spanish Olympic Committee (reformed and established as a permanent entity)

1926 Fencing

1927 Chess

1928 Billiards

1932 Wrestling

1934 Golf 